\title{
JURNAL PENELITIAN KEPERAWATAN
}

\author{
Volume 5, No. I, Januari 2019
}

Hubungan Response Time Perawat dengan Tingkat Kepuasan Pasien BPJS di Instalasi Gawat Darurat

Hubungan Tipe Kepribadian dengan Partisipasi Belajar Kelompok Mahasiswa Prodi Ners

Penggunaan Metode Simulasi dalam Peningkatan Critical Thinking: Literature Review

Pentingnya Self-Directed Learning Readiness (SDLR) Terhadap Motivasi Belajar, Manajemen Diri dan Pengendalian Diri pada Mahasiswa Kesehatan: A Literature Review

Metode Massage terhadap Tekanan Darah pada Penderita Hipertensi: A Literatur Review

Pengaruh Permainan Ular Tangga terhadap Perilaku Hidup Bersih dan Sehat (PHBS) pada Anak Sekolah Dasar

Penilaian Tumbuh Kembang dengan Dukungan Anticipatory Guidance pada Anak di Tempat Penitipan Anak

Hubungan Kadar Gula Darah Sewaktu dengan Gejala Neuropati Perifer Penderita Diabetes Melitus Tipe 2

Pengalaman Remaja Saat Menghadapi Manarche

Adaptasi Psikologis pada Ibu Post Partum Primigravida (Fase Taking Hold) Sectio Caesarea dan Partus Normal

Diterbitkan oleh

STIKES RS. BAPTIS KEDIRI

\begin{tabular}{|c|c|c|c|c|c|}
\hline $\begin{array}{c}\text { Jurnal Penelitian } \\
\text { Keperawatan }\end{array}$ & Vol.5 & No.1 & $\begin{array}{c}\text { Hal } \\
1-87\end{array}$ & $\begin{array}{c}\text { Kediri } \\
\text { Januari 2019 }\end{array}$ & 2407-7232 \\
\hline
\end{tabular}




\title{
JURNAL PENELITIAN KEPERAWATAN
}

\author{
Volume 5, №. I, Januari 2019
}

\author{
Penanggung Jawab \\ Aries Wahyuningsih, S.Kep., Ns., M.Kes
}

Ketua Penyunting

Srinalesti Mahanani, S.Kep., Ns., M.Kep

\section{Sekretaris}

Desi Natalia Trijayanti Idris, S.Kep., Ns., M.Kep

\section{Bedahara}

Dewi Ika Sari H.P., SST., M.Kes

\section{Penyunting Ahli:}

Dr. Titih Huriah, S.Kep., Ns., M.Kep., Sp.Kom

Penyunting Pelaksana

Aries Wahyuningsih, S.Kep., Ns., M.Kes

Tri Sulistyarini, A.Per Pen., M.Kes

Dewi Ika Sari H.P., SST., M.Kes

Erlin Kurnia, S.Kep., Ns., M.Kes

Dian Prawesti, S.Kep., Ns., M.Kep

Maria Anita Yusiana, S.Kep., Ns., M.Kes

\section{Sirkulasi}

Heru Suwardianto, S.Kep., Ns M.Kep

\section{Diterbitkan Oleh:}

STIKES RS. Baptis Kediri

Jl. Mayjend Panjaitan No. 3B Kediri

Email: uuptppmstikesbaptis@gmail.com

Link: http://jurnalbaptis.hezekiahteam.com/jurnal 


\title{
JURNAL PENELITIAN KEPERAWATAN
}

\author{
Volume 5, №. I, Januari 2019
}

\section{DAFTAR ISI}

Hubungan Response Time Perawat dengan Tingkat Kepuasan Pasien BPJS di Instalasi Gawat Darurat

Samfriati Sinurat | Indra Hizkia Perangin-angin | Josephine Christabel Lombu Sepuh

Hubungan Tipe Kepribadian dengan Partisipasi Belajar Kelompok Mahasiswa Prodi Ners

Lilis Novitarum | Mardiati Barus | Timo Rauli Lumban Gaol

Penggunaan Metode Simulasi dalam Peningkatan Critical Thinking: Literature Review

Achmad Vindo Galaresa | Sri Sundari

Pentingnya Self-Directed Learning Readiness (SDLR) Terhadap Motivasi Belajar, Manajemen Diri dan Pengendalian Diri pada Mahasiswa Kesehatan: $A$ Literature Review

Wahyu Riyaningrum | Wiwik Kusumawati

Metode Massage terhadap Tekanan Darah pada Penderita Hipertensi: A Literatur Review

Ardiansyah | Titih Huriah

Pengaruh Permainan Ular Tangga terhadap Perilaku Hidup Bersih dan Sehat (PHBS) pada Anak Sekolah Dasar

Dhita Kris Prasetyanti | Galuh Pradian Yanuaringsih

Penilaian Tumbuh Kembang dengan Dukungan Anticipatory Guidance pada Anak di Tempat Penitipan Anak

Sandy Kurniajati | Kili Astarani | Dewi Ika Sari Hari Poernomo

Hubungan Kadar Gula Darah Sewaktu dengan Gejala Neuropati Perifer 61-66 Penderita Diabetes Melitus Tipe 2

Supriyadi | Susmini

Pengalaman Remaja Saat Menghadapi Manarche

$67-75$

Lilik Setiawan | Sutiyah Heny | Reni Linda Saputri 
Adaptasi Psikologis pada Ibu Post Partum Primigravida (Fase Taking Hold) 76-82 Sectio Caesarea dan Partus Normal

Dian Taviyanda 


\title{
PENTINGNYA SELF-DIRECTED LEARNING READINESS (SDLR) TERHADAP MOTIVASI BELAJAR, MANAJEMEN DIRI DAN PENGENDALIAN DIRI PADA MAHASISWA KESEHATAN: A LITERATURE REVIEW
}

\author{
THE IMPORTANCE OF SELF-DIRECTED LEARNING READINESS (SDLR) TO \\ THE LEARNING MOTIVATION, SELF MANAGEMENT AND SELF CONTROL \\ OF HEALTH STUDENTS: A LITERATURE REVIEW
}

\author{
Wahyu Riyaningrum*, Wiwik Kusumawati** \\ * Mahasiswa Prodi Magister Keperawatan Universitas Muhammadiyah Yogyakarta \\ **Dosen Fakultas Kedokteran dan Ilmu Keperawatan, Universitas Muhammadiyah \\ Yogyakarta \\ Email: ady.irawan.am@gmail.com
}

\begin{abstract}
ABSTRAK
Self-Directed LearningReadiness (SDLR) sebagai tingkat individu memiliki sikap, kemampuan dan karakteristik kepribadian yang diperlukan untuk pembelajaran mandiri. Tujuan literatur review ini menganalisis tentang pentingnya SDLR terhadap motivasi belajar, manajemen diri dan pengendalian diri pada mahasiswa kesehatan. Desain Literature review. Metode menggunakan database dengan penelusuran elektronik pada PubMed, ProQuest, Google Scholar, JPKI dan yang dipublikasikan pada tahun 20112017. Hasil Enam artikel dipakai dalam review. Lima artikel menunjukkan tingkat SDLR tinggi, Kesiapan belajar mandiri yang tinggi menunjukkan adanya kemampuan mahasiswa untuk mengembangkan prinsip-prinsip self-derected, untuk mengembangkan diri sangat disarankan agar mahasiswa mengelola proses belajar mereka sendiri melalui keterlibatan secara aktif, pandai mengambil inisiatif dan memiliki motivasi tinggi. Mahasiswa diharapkan mampu memiliki 3 dimensi SDL dengan kesiapan tinggi untuk belajar mandiri di pendidikan sarjana dan kepaniteraan. Kesimpulan dari literature review ini Kesiapan mahasiswa untuk belajar mandiri sangat dibutuhkan untuk meningkatkan motivasi belajar, manajemen diri dan pengendalian diri pada mahasiswa kesehatan.
\end{abstract}

\section{Kata kunci: Self-directed learning readiness, Kesiapan, Pembelajaran}

\begin{abstract}
Self-Directed Learning Readiness (SDLR) as the individual has the attitudes, abilities and personality characteristics required for self-learning. Objective literature review analyzes the importance of SDLR to the learning motivation, self-management and self-control of health students. Design is literature review. Method using a database with electronic search on PubMed, ProQuest, Google Scholar, JPKI and published in 20112017. Result six articles are used in the review. Five articles show high levels of SDLR, high self-study readiness indicates the ability of students to develop self-derived principles, to develop themselves it is strongly recommended that students manage their own learning process through active engagement, clever take initiative and have high motivation. Students are expected to have 3 dimensions of SDL with high readiness for
\end{abstract}


independent study in undergraduate and college students. Conclusion the readiness of the students to learn independently is needed to improve the learning motivation, selfmanagement and self-control of health students.

\section{Keywords: Self-directed learning readiness, Readiness, Learning}

\section{Pendahuluan}

Pendekatan pembelajaran modern semakin sedikit terstuktur dalam kegiatan belajar dan lebih banyak tugas belajar mandiri dipandu melalui konsultasi dengan akademisi (Stewart, 2007) selfderected learning (SDL) telah menjadi fokus pendidikan keperawatan di beberapa dekade karena kompleksitas dan perubahan perkembangan profesi keperawatan (Safavi, 2010). Hal ini digunakan baik di program sarjana, tahap kepaniteraan dan program pasca (Fisher and King, 2010) menuntut kebutuhan tenaga perawat profesional untuk memperbarui pengetahuan mereka menjadi otonom, mampu berfikir mandiri dan mampu membuat keputusan sendiri (El-Gilany and Abusaad, 2013).

Kesiapan belajar mandiri yang tinggi menunjukkan adanya kemampuan mahasiswa untuk mengembangkan prinsip-prinsip self-derected: manajemen diri, keinginan untuk belajar, dan pengendalian diri (Deyo et al., 2011) rata-rata SDLR 148,6; (El-Gilany and Abusaad, 2013) 159,6; (Shaikh, 2013) 214,7; (Slater et al., 2017) 215,53; (Seesy et al., 2017) 180,6. (Gunanegara et al., 2017) rerata penerapan SDL pada kelompok mahasiswa tahun pertama dan kelompok mahasiswa kepaniteraan $\mathrm{p}=0,349$. Memiliki SDLR yang berkualitas penting untuk mengatasi kegagalan belajar dan kegagalan psikologi dimulai dari anak-anak sampai orang dewasa (Deyo et al., 2011).

Pada beberapa institusi pendidikan yang sudah melakukan penelitian tentang kesiapan penerapan SDLR pada kelompok mahasiswa tahun pertama dan mahasiswa kepaniteraan (Cooper et al.,
2015) faktor yang berperan dalam kesiapan mahasiswa meliputi: karakteristik mahasiswa yang belum siap, proses pembelajaran tidak optimal, peran tutor atau perseptor kurang mendukung dan sarana penunjang pembelajaran tidak adekuat (Gunanegara et al., 2017). Berdasarkan permasalahan tersebut, literature review ini menganalisis tentang pentingnya SDLR terhadap motivasi belajar, manajemen diri dan pengendalian diri pada mahasiswa kesehatan.

\section{Metodologi Penelitian}

Studi ini dilakukan melalui tiga tahap: 1) Memanfaatkan database akademik, penyusun mencari dan mengambil artikel dan sumber daya yang relevan dengan topik yang dikaji. 2) Penyusun memilih artikel dan sumber yang diambil untuk mengidentifikasi jurnal yang paling mungkin menawarkan data pendukung. 3) Penyusun mengumpulkan informasi, grafik dan tabel data, dengan harapan mengidentifikasi dan memprioritaskan intervensi. Database digunakan dalam proses pencarian penyusun, termasuk Sumber Pubmed, Proquest, Google Scholar dan JPKI. Kata kunci dan istilah pencarian yang digunakan: self directed learning readiness, readiness, dan learning. 


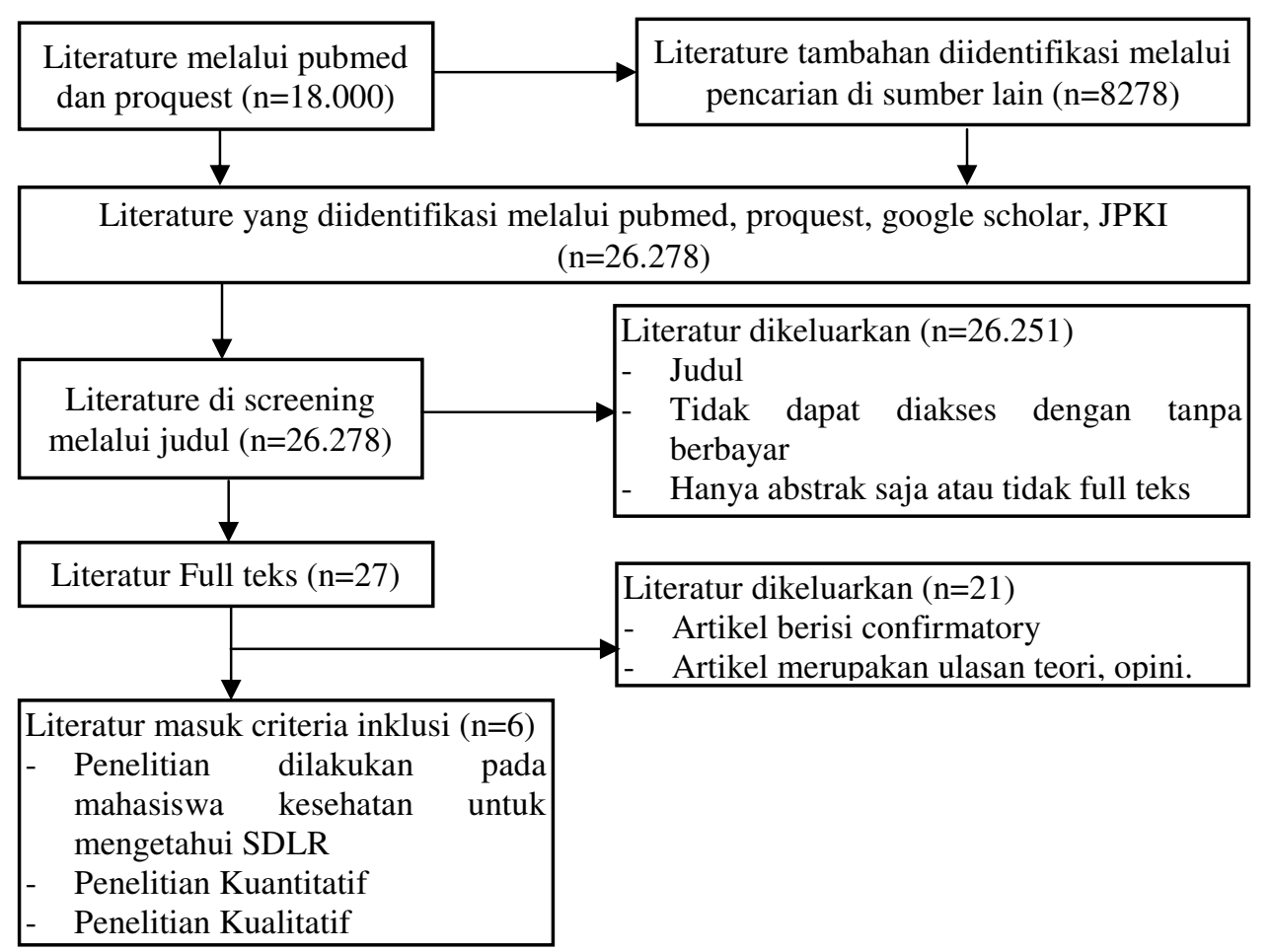

Gambar 1. Proses tinjauan literature review

\section{Hasil Penelitian}

Hasil kajian literatur ini mengidentifikasikan enam artikel yang memenuhi kriteria inklusi. Sebagian besar makalah membahas tentang kesiapan belajar mandiripada mahasiswa sarjana kesehatan dan kepaniteraan. Artikel yang ditulis dalam Bahasa Indonesia hanya satu artikel, sedangkan artikel lainnya ditulis dalam bahasa Inggris. Berkenaan dengan hasil penelitian yang didapatkan tingkat Self-
Directed Learning Readiness (SDLR) yang tinggi ada lima artikel, yang satu masuk dalam kategori tingkat SDLR yang rendah. Jenis penelitian yang digunakan adalah penelitian kuantitative untuk mengetahui tingkat kesiapan belajar mandiri pada mahasiswa dan hanya satu penelitian dengan menggunakan mixmethod, dimana kualitatif disini untuk mengetahui faktorfaktor yang berperan besar dalam mengetahui kesiapan penerapan SDL. Hasil literature review dapat dilihat pada tabel di bawah ini:

Tabel 1. Hasil Literatur Review

\begin{tabular}{|c|c|c|c|c|c|}
\hline $\begin{array}{l}\text { Author } \\
\text { (year) }\end{array}$ & Language & $\begin{array}{c}\text { Design and } \\
\text { data collection } \\
\text { methods }\end{array}$ & Aim & Findings & Component \\
\hline $\begin{array}{l}\text { (Deyo et } \\
\text { al., 2011) }\end{array}$ & English & $\begin{array}{l}\text { Quantitative } \\
\text { A descriptive, } \\
\text { cross-sectional, } \\
\text { study. A survey } \\
\text { instrument. }\end{array}$ & 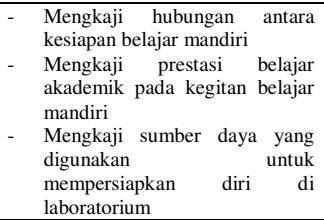 & $\begin{array}{l}\text { - Kesiapan mahasiswa tinggi } \\
\text { untuk belajar mandiri } \\
\text { - Tidak ada hubungan yang } \\
\text { signifikan antara nilai akademik } \\
\text { dan SDLR }\end{array}$ & $\begin{array}{ll}- & \text { SDLR } \\
- & \text { Nilai Akademik }\end{array}$ \\
\hline $\begin{array}{l}\text { Slater et } \\
\text { al., } \\
\text { (2017) }\end{array}$ & English & $\begin{array}{l}\text { Quantitative } \\
\text { A single cohort } \\
\text { cross-sectional } \\
\text { survey design }\end{array}$ & 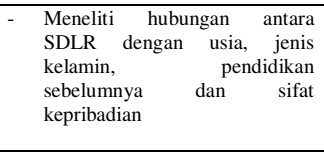 & $\begin{array}{ll}- & \text { Menunjukkan nilai SDLR tinggi } \\
\text { - SDLR meningkat seiring dengan } \\
\text { bertambahnya usia, tingkat } \\
\text { pendidikan dan nilai kepribadian } \\
- \\
\text { Perempuan nilai SDLR lebih } \\
\text { tinggi dari pada laki-laki }\end{array}$ & $\begin{array}{ll}- & \text { SDLR } \\
\text { - } & \text { Karakteristik usia } \\
\text { - } & \text { Karakteristik JK } \\
\text { - } & \text { Tingkat pendidikan } \\
\text { - } & \text { Kepribadian }\end{array}$ \\
\hline
\end{tabular}




\begin{tabular}{|c|c|c|c|c|c|}
\hline $\begin{array}{l}\text { Author } \\
\text { (year) }\end{array}$ & Language & $\begin{array}{c}\text { Design and } \\
\text { data collection } \\
\text { methods }\end{array}$ & Aim & Findings & Component \\
\hline $\begin{array}{l}\text { El-Gilany } \\
\text { and Abusaad, } \\
\text { (2013). }\end{array}$ & English & $\begin{array}{l}\text { Quantitative } \\
\text { Cross-sectional }\end{array}$ & $\begin{array}{l}\text { Untuk mengetahui kesiapan } \\
\text { mahasiswa keperawatan } \\
\text { Saudi Arabia untuk belajar } \\
\text { mandiri } \\
\text { - Untuk mengidentifikasi gaya } \\
\text { belajar } \\
\text { - Untuk mengetahui hubungan } \\
\text { antara kedua konsep tersebut }\end{array}$ & $\begin{array}{l}\text { Menunjukkan nilai SDLR tinggi } \\
\text { - } \text { Gaya belajar konvergen yang } \\
\text { dominan } 35,6 \% \text { pada mahasiswa } \\
\text { keperawatan } \\
\text { - Tidak ada hubungan antara } \\
\text { tingkat SDLR dan gaya belajar }\end{array}$ & $\begin{array}{ll}\text { - } & \text { SDLR } \\
\text { - } & \text { Gaya belajar }\end{array}$ \\
\hline $\begin{array}{l}\text { Shaikh, } \\
\text { (2013) }\end{array}$ & English & $\begin{array}{l}\text { Quantitative } \\
\text { Quasi- } \\
\text { exsperimen }\end{array}$ & $\begin{array}{lr}\text { Untuk } & \text { membandingkan } \\
\text { kesiapan pembelajaran } & \text { mandiri antara siswa dengan } \\
\text { kurikulum konvensional } & \text { konvan kurikulum terpadu: } \\
\text { dengan } & \text { Integrated Organ System } \\
\text { Based Curiculum (IOSBC) }\end{array}$ & $\begin{array}{l}\text { Menunjukkan nilai SDLR tinggi } \\
\text { Tidak menemukan perbedaan } \\
\text { dalam kesiapan belajar mandiri } \\
\text { antara mahasiswa kedokteran } \\
\text { dengan kurikulum konvensional } \\
\text { dan kurikulum terpadu. }\end{array}$ & $\begin{array}{ll}- & \text { SDLR } \\
- & \text { Kurikulum } \\
& \text { konvensional } \\
- & \text { Kurikulum terpadu } \\
\text { (IOSBC) }\end{array}$ \\
\hline $\begin{array}{l}\text { Gunanegara } \\
\text { et al., (2017). }\end{array}$ & Indonesia & $\begin{array}{l}\text { Mixed } \\
\text { methods }\end{array}$ & $\begin{array}{ll}\text { - Untuk mengetahui tingkat } \\
\text { motivasi diri, } \\
\text { Kesiapan penerapan SDL } \\
\text { pada mahasiswa kedokteran } \\
\text { - Mengidentifikasi faktor- } \\
\text { faktor yang memengaruhinya }\end{array}$ & $\begin{array}{l}\text { Motivasi yang tinggi pada } \\
\text { mahasiswa kedokteran } \\
\text { - Kesiapan penerapan SDL } \\
\text { menunjukkan tingkat yang } \\
\text { rendah } \\
\text { - Faktor yang berperan dalam } \\
\text { kesiapan penerapan SDL pada } \\
\text { mahasiswa yaitu karakteristik } \\
\text { mahasiswa yang belum siap, } \\
\text { proses pembelajaran yang tidak } \\
\text { optimal, peran tutor/preseptor } \\
\text { yang kurang mendukung dan } \\
\text { sarana penunjang pembelajaran } \\
\text { tidak adekuat } \\
\end{array}$ & $\begin{array}{llr} & \text { SDLR } \\
- & \text { Motivasi diri } \\
- & \text { Faktor-faktor yang } \\
& \text { berperan dalam } \\
& \text { kesiapan SDL }\end{array}$ \\
\hline $\begin{array}{l}\text { (Seesy et al., } \\
2017)\end{array}$ & English & $\begin{array}{l}\text { Quantitative } \\
\text { A cross } \\
\text { sectional }\end{array}$ & 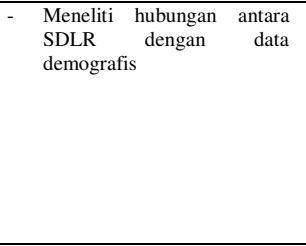 & $\begin{array}{l}\text { Menunjukkan nilai SDLR tinggi } \\
\text { - Mahasiswa perawat usia 30-40 } \\
\text { th memiliki manajemen diri } \\
\text { yang tinggi dibandingkan usia } \\
\text { kurang dari } 20 \text { th } \\
\text { - Tidak ada perbedaan signifikan } \\
\text { antara data demografis dengan } \\
\text { SDLR }\end{array}$ & $\begin{array}{ll}- & \text { SDLR } \\
\text { - } & \text { Karakteristik usia } \\
- & \text { Status perkawinan } \\
- & \text { Tempat tinggal } \\
\text { permanen } \\
\text { - } & \text { Pengalaman kerja } \\
- & \text { Jumlah rata-rata } \\
& \text { perminggu untuk } \\
& \text { belajar dan persiapan } \\
& \text { mengerjakan tugas } \\
\end{array}$ \\
\hline
\end{tabular}

\section{Implementasi Self-Directed Learning (SDL)}

Self-Directed Learning (SDL)
sebagai metode pengajaran yang
digunakan dalam pendidikan orang
dewasa dan dibutuhkan bagi mahasiswa
keperawatan, untuk dipersiapkan untuk
masa kini dan juga tantangan masa depan
dalam sistem layanan kesehatan. Untuk
mengembangkan diri, sangat disarankan
agar mahasiswa mengelola proses belajar
mereka sendiri melalui keterlibatan.
Pembelajaran yang diarahkan langsung
dapat diartikan dalam hal tanggung
jawab yang diberikan mahasiswa untuk
pembelajarannya sendiri (Seesy et al.,
2017), (Slater et al., 2017) dan
(Gunanegara et al., 2017)
menggambarkan SDL sebagai proses di
mana individu mengambil inisiatif,
dengan atau tanpa bantuan orang lain,
dalam mendiagnosis kebutuhan belajar
mereka, merumuskan pembelajaran
tujuan, identifikasi sumber daya manusia
dan material untuk belajar, memilih dan
menerapkan strategi pembelajaran yang

tepat, dan mengevaluasi hasil belajar SDL sebagai pendekatan proaktif untuk belajar dimana individu bertanggung jawab untuk mengidentifikasi sumber belajar yang diperlukan dan menerapkan strategi yang sesuai dengan tujuan mereka.

Penerapan SDL merupakan interaksi beberapa aspek, yaitu motivasi diri, pengaturan diri (self management), dan keterampilan memonitor diri (self monitoring skill) (Gunanegara et al., 2017) Pendapat lain (Slater et al., 2017) mengungkapkan bahwa SDL memiliki banyak manfaat kepada mahasiswa termasuk peningkatan kepercayaan diri, otonomi, motivasi dan persiapan untuk pembelajaran sepanjang hayat. Kesiapan mahasiswa untuk terlibat dalam SDL telah diartikan sejauh mana mahasiswa memiliki sikap, kemampuan dan karakteristik kepribadian yang diperlukan untuk pembelajaran mandiri (Guglielmino, 2013) Mahasiswa melihat masalah sebagai tantangan, keinginan berubah, menikmati belajar, sangat termotivasi untuk belajar, gigih, mandiri, disiplin diri, percaya diri dan berorientasi 
pada tujuan hal ini diuangkapkan oleh (Shaikh, 2013)

\section{Faktor-faktor yang mempengaruhi SDL}

Model pembelajaran androgogis mengarahkan mahasiswa untuk mengarahkan dirinya sendiri, berpengalaman dan memiliki motivasi. Motivasi disini mengacu pada pengaruh internal dan eksternal terhadap nilai dan keberhasilan (Deyo et al., 2011) Motivasi berperan sangat penting dalam menerapkan SDL (Gunanegara et al., 2017). Pada penelitian kualitatif Guna Negara menyatakan bahwa ada 4 faktor yang yang berperan besar dalam kesiapan penerapan SDL mahasiswa: 1) Karakteristik mahasiswa yang belum siap belajar, 2) Proses pembelajaran yang tidak optimal, 3) Peran tutor atau perseptor yang kurang mendukung, 4) Sarana penunjang pembelajaran tidak adekuat. Dari keempat faktor tersebut yang menunjukkan tingkat kesiapan penerapan SDL yang rendah. Di sisi lain karakteristik mahasiswa meliputi kurangnya pengalaman pembelajaran student centered di SMA dan masih rendahnya motivasi diri yang dimiliki mahasiswa. Sarana penunjang menjadi kendala untuk terwujudnya proses pembelajaran yang optimal meliputi sarana perpustakaan dan fasilitas akses internet.

\section{Dimensi dalam SDL}

SDL mencakup tiga dimensi; 1) manajemen diri; 2) keinginan untuk belajar; dan 3) pengendalian diri. 1) Sub skala Manajemen Mandiri adalah konstruk kemampuan mahasiswa untuk dapat menerapkan tujuan pembelajaran mereka sendiri, dan secara efektif mengelola sumber belajar yang tersedia bagi mereka. Sub skala ini mencakup komponen seperti a). Kemampuan untuk mengatur waktu secara efektif, b). Kemampuan menerapkan pendekatan pembelajaran yang sistematis dan metodis, c) Mengatur waktu untuk belajar d). Memprioritaskan dan mencari informasi tambahan dan sumber daya, e) Pemecahan masalah. Ini menggambarkan mahasiswa menetapkan tujuan dan mengelola sumber daya dan dukungan yang ada (Seesy et al., 2017) Selain itu, para mahasiswa mengasumsikan tanggung jawab utama untuk merencanakan, menerapkan, dan mengevaluasi proses belajar. 2) Desire for Learning Subscale diterapkan pada mahasiswa yang berpartisipasi untuk menentukan motivasi belajar mereka, keinginan untuk belajar mengasumsikan tanggung jawab untuk belajar. 3) SelfControl Subscale digunakan untuk menentukan kemampuan mahasiswa mengevaluasi diri dan hasilnya menentukan tujuan dan hasil belajar mereka sendiri. Kontrol diri berarti mahasiswa mengambil kendali konteks pembelajaran untuk mencapai tujuan pembelajaran mereka. Kontrol tidak berarti independensi, melainkan berkolaborasi dengan orang lain dalam konteksnya (Deyo et al., 2011).

\section{Pengukuran Self-Directed Learning Readiness (SDLR)}

Self-Directed Learning Readiness (SDLR) (Deyo et al., 2011) dan (ElGilany and Abusaad, 2013) sebagai tingkat individu memiliki sikap, kemampuan dan karakteristik kepribadian yang diperlukan untuk pembelajaran mandiri. Menurut (Rossler and Kimble, 2016) untuk sarjana pendidikan keperawatan dalam membantu pendidik perawat dalam diagnosis sikap mahasiswa, kemampuan dan karakteristik kepribadian yang diperlukan untuk belajar mandiri. (Guglielmino, 2013) Self-Directed Learning Readiness Scale (SDLRS) merupakan alat yang divalidasi yang dapat digunakan untuk mengukur tingkat 
kemampuan individu yang memiliki karakteristik, kemampuan dan memiliki kepribadian yang diperlukan untuk pembelajaran mandiri. (Slater et al., 2017) menyatakan SDLRS sebagai instrumen yang paling umum digunakan untuk mengukur tingkat kesiapan belajar mandiri pada bidang kesehatan. (Guglielmino, 2013) mengemukakan SDLRS terdiri dari 40 item yang dikelompokkan dalam tiga subskala yaitu; manajemen diri yang mencerminkan karakteristik keberadaan ini mampu mengelola pembelajaran sendiri (13 item), keinginan untuk belajar (12 item), dan karakteristik pengendalian diri atau berada dalam kendali seseorang belajar sendiri (15 item). Mahasiswa menanggapi dengan menggunakan Likert 5 poin skala yang berkisar dari 5 untuk sangat setuju untuk 1 untuk sangat tidak setuju. Nilai keseluruhan bisa berkisar antara 40 sampai 200 , dengan nilai yang lebih tinggi mencerminkan kesiapan yang lebih kuat untuk belajar mandiri.

\section{Pembahasan}

Tinjauan literatur ini telah menggaris bawahi tentang kesiapan mahasiswa untuk belajar mandiri artikelartikel yang sudah dilaporkan ternyata menyebutkanmahasiswa dilakukan penelitian pada semester awal tahap akademik sarjana dan tahap kepaniteraan dimana mahasiswa dituntut untuk dapat mengikuti proses pembelajaran dan menghadapi dunia praktek klinik di lahan.

Self-directed Learning (SDL) telah menjadi fokus pendidikan kesehatan baik itu kedokteran, keperawatan maupun farmasi dalam beberapa dekade terakhir karena kompleksitas dan banyaknya perubahan dalam pengembangan profesi kesehatan (Deyo et al., 2011), (Slater et al., 2017), (ElGilany and Abusaad, 2013) dan (Gunanegara et al., 2017) Pembelajaran mandiri dicapai saat mahasiswa mengarahkan dan mengatur proses belajar mereka sendiri dan mengalami aktualisasi diri dengan menentukan materi, metode dan tujuan pembelajaran, hal ini disesuaikan dengan kesiapan untuk terbiasa belajar mandiri (Deyo et al., 2011). Untuk mengukur tingkat kesiapan mahasiswa dalam belajar mandiri menggunakan Self-Directed Learning Readiness (SDLR) (Guglielmino, 2013). Dengan adanya kesiapan yang tinggi akan mempengaruhi proses pembelajaran, dalam penelitian di Universitas King Abdul Aziz Arab Saudi, dengan alasan mahasiswa harus memiliki kesiapan belajar mandiri yang tinggi, maka kebijakan Negara Arab Saudi untuk pendidikan menekankan pendekatan pembelajaran berpusat pada mahasiswa dan mendukung proses belajar mengajar untuk mempromosikan mahasiswa yang mengarahkan dirinya sendiri (Seesy et al., 2017) hasil kesiapan belajar mandiri yang tinggi juga sesuai dengan penelitian (Deyo et al., 2011) dan (Slater et al., 2017).

Pada kesiapan belajar mandiri dinilai berkenaan dengan tiga dimensi: kontrol diri, keinginan untuk belajar dan manajemen diri (El-Gilany and Abusaad, 2013) hasilnya pada pengendalian diri didapatkan persentase kesiapan tertinggi, menunjukkan kepercayaan dan kematangan mahasiswa keperawatan, persentase kesiapan kedua yang didapat dari keinginan diri, dan yang terakhir dari pengelolaan diri merupakan persentase kesiapan yang terendah, hal ini menunjukkan bahwa mahasiswa memerlukan dukungan dalam keterampilan pengelolaan mandiri. (Slater et al., 2017) selain tiga dimensi tersebut ada point kepribadian mahasiswa yang menunjukkan ada hubungan terhadap nilai SDLR.

Dilihat dari karakteristik usia dan jenis kelamin mahasiswa, kemampuan manajemen mandiri pada mahasiswa yang lebih tua memiliki nilai SDLR lebih tinggi dari yang usianya lebih muda (Slater et al., 2017) menurut (Seesy et $a l ., 2017)$ menyatakan hal yang sama bahwa pada kesiapan manajemen mandiri pada mahasiswa perawat yang 
berusia 30-40 tahun memiliki kemampuan manajemen mandiri yang lebih tinggi dibandingkan kelompok usia kurang dari 20 tahun. Karakteristik kesiapan dilihat dari jenis kelamin pada mahasiswa yang berjenis kelamin perempuan menunjukkan nilai SDLR yang tinggi dibandingkan dengan nilai kesiapan belajar mandiri SDLR yang lebih rendah pada laki-laki (Slater et al., 2017) berbeda pendapat dengan (Shaikh, 2013) menunjukkan bahwa tidak ditemukan perbedaan yang signifikan antara mahasiswa perempuan dan lakilaki terhadap nilai SDLR.

Mengenai prestasi akademik (Deyo et al., 2011) tidak ada hubungan yang signifikan antara nilai akademik dengan SDLR, penilaian menggunakan SDLR Fisher berlaku untuk memprediksi hubungan antara kesiapan untuk belajar mandiri dan kebiasaan belajar mandiri, namun mungkin tidak berguna untuk memprediksi hubungan kesiapan dengan prestasi akademik. Pada penelitian (Gunanegara et al., 2017) kesiapan penerapan SDL menunjukkan tingkat yang rendah, hal ini justru yang berperan adalah motivasi, dimana motivasi yang tinggi digambarkan pada mahasiswa di Universitas Kristen Maranatha Bandung, Indonesia. Penerapan SDL yang digunakan pada metode pembelajaran Problem Based Learning (PBL) sebagai pendekatan pembelajaran yang mendorong mahasiswa untuk berperan aktif dalam melakukan proses belajarnya (Efendy, 2009), mahasiswa dapat mengembangkan pengetahuan mereka secara mandiri. Pada mahasiswa dalam kelompok Project-Based Learning (PoBL) ditemukan pembelajaran mandiri lebih baik dibandingkan dengan mereka yang menggunakan metode konvensional (Bagheri et al., 2013) PoBL memberikan gagasan inovatif, pada metode pembelajaran konvensional mahasiswa terbiasa mendengarkan secara pasif dan hanya mengikuti instruksi guru, mahasiswa kurang terpapar dengan belajar mandiri.

Kendala lain pada responden yang memiliki tingkat kesiapan SDLR rendah, mereka menyatakan bahwa ada perasaan ragu-ragu mengenai rencana karier mereka ke depannya (Deyo et al., 2011) menurut Deyo, mahasiswa yang memiliki SDLR yang berkualitas tinggi dapat mengatasi kegagalan dalam belajar dan kegagalan psikologi dimulai dari usia anak-anak sampai orang dewasa. Tingginya tingkat SDLR dan belajar konvergen yang dominan dikalangan mahasiswa sarjana keperawatan akan memiliki implikasi positif untuk pendidikan keperawatan dan setelah mereka bekerja (El-Gilany and Abusaad, 2013).

\section{Keterbatasan}

Ini adalah ulasan komprehensif tentang literatur dan mungkin juga dianggap terbatas karena tidak ada penilaian kritis yang eksplisit dilakukan pada materi yang disajikan, berbeda dengan sistematis review. Keputusan untuk tidak melakukan yang sistematis review didasarkan pada sifat dari pertanyaan dan berusaha menjawab yang spesifik pertanyaan. Selain itu, diakui bahwa kesiapan mahasiswa terhadap pembelajaran mandiri masih banyak yang belum dilakukan penelitian.

\section{Kesimpulan}

Kesiapan mahasiswa untuk belajar mandiri sangat dibutuhkan untuk meningkatkan motivasi belajar, manajemen diri dan pengendalian diri pada mahasiswa kesehatan. Mahasiswa dapat mengembangkan pengetahuan mereka secara mandiri dengan pendekatan pembelajaran yang mendorong mahasiswa untuk berperan aktif dalam melakukan proses belajarnya. 


\section{Daftar Pustaka}

Bagheri, M., Ali, W.Z.W., Abdullah, M.C.B., Daud, S.M., 2013. Effects of project-based learning strategy on self-directed learning skills of educational technology students. Contemp. Educ. Technol. 4, 1529.

Casey, K., Fink, R., Jaynes, C., Campbell, L., Cook, P., Wilson, V., 2011. Readiness for Practice: The Senior Practicum Experience. J. Nurs. Educ. 50, 646-652. https://doi.org/10.3928/0148483420110817-03

Cooper, J., Courtney-Pratt, H., Fitzgerald, M., 2015. Key influences identified by first year undergraduate nursing students as impacting on the quality of clinical placement: A qualitative study. Nurse Educ. Today 35, 1004 1008.

https://doi.org/10.1016/j.nedt.2015.03.00 9

Deyo, Z.M., Huynh, D., Rochester, C., Sturpe, D.A., Kiser, K., 2011. Readiness for self-directed learning and academic performance in an abilities laboratory course. Am. J. Pharm. Educ. 75, 25.

Efendy, N. F. (2009). Pendidikan dalam keperawatan. Jakarta: Salemba Medika.

El-Gilany, A.-H., Abusaad, F.E.S., 2013. Self-directed learning readiness and learning styles among Saudi undergraduate nursing students. Nurse Educ. Today 33, 10401044.

https://doi.org/10.1016/j.nedt.2012 .05 .003

Fisher, M.J., King, J., 2010. The selfdirected learning readiness scale for nursing education revisited: A confirmatory factor analysis. Nurse Educ. Today 30, 44-48. https://doi.org/10.1016/j.nedt.2009 .05 .020
Guglielmino, L.M., 2013. The case for promoting self-directed learning in formal educational institutions. SA-EDUC 10.

Gunanegara, R.F., Wahid, M.H., Widyahening, I.S., 2017. Comparison of Students' Characteristics, Self-Motivation, and Readiness of Self-Directed Learning Implementation among Medical Students at Maranatha Christian University. J. Med. Health 1.

Hidayat, R., Muhlisin, A., KM, S., Kes, M., Dewi, E., Kep, S., 2015. Hubungan Antara Minat Dan CitaCita Dengan Motivasi Belajar Mahasiswa Program Studi S1 Keperawatan di Universitas Muhammadiyah Surakarta. Universitas Muhammadiyah Surakarta.

Levett-Jones, T., Pitt, V., Courtney-Pratt, H., Harbrow, G., Rossiter, R., 2015. What are the primary concerns of nursing students as they prepare for and contemplate their first clinical placement experience? Nurse Educ. Pract. 15, 304-309.

https://doi.org/10.1016/j.nepr.2015.03.01 2

Musiana, M., 2017. Problem based learning (pbl) dalam upaya meningkatkan hasil belajar dan pemahaman mahasiswa keperawatan terhadap asuhan keperawatan medikal bedah. J. Keperawatan 9, 43-48.

Porter, A.L., Barnett, S.G., Gallimore, C.E., 2017. Development of a holistic assessment plan to evaluate a four-semester laboratory course series. Am. J. Pharm. Educ. 81, 33.

Rossler, K.L., Kimble, L.P., 2016. Capturing readiness to learn and collaboration as explored with an interprofessional simulation scenario: A mixed-methods research study. Nurse Educ. Today 36, 348-353. 
https://doi.org/10.1016/j.nedt.2015 .08 .018

Safavi, et. al. (2010). Self-directed learning readiness and learning styles among nursing students of Isfahan University of medical sciences. Iranian Journal of Medical Education 10 (1), 27-35.

Seesy et al. (2017). Self-directed learning readiness among nursing students at King Abdul Aziz University Saudi Arabia. IORS Journal of Nursing and Health Science, 1424.

Shaikh, R.B., 2013. Comparison of readiness for self-directed learning in students experiencing two different curricula in one medical school. Gulf Med. J. 2, 27-31.

Slater, C.E., Cusick, A., Louie, J.C.Y., 2017. Explaining variance in selfdirected learning readiness of first year students in health professional programs. BMC Med. Educ. 17. https://doi.org/10.1186/s12909017-1043-8

Stewart, R. (2007). Investigating the link between self-directed learning readiness and project-based learning outcomes. European Journal of Engineering education 32 (4) , 453-465

Zhang, C., Fan, H., Xia, J., Guo, H., Jiang, X., Yan, Y., 2017. The Effects of Reflective Training on the Disposition of Critical Thinking for Nursing Students in China: A Controlled Trial. Asian Nurs. Res. 11, 194-200.

https://doi.org/10.1016/j.anr.2017.07.002 